\title{
NUTRITIONAL POTENTIAL OF GREEN BANANA FLOUR OBTAINED BY DRYING IN SPOUTED BED ${ }^{1}$
}

\author{
CAROLINA VIEIRA BEZERRA², ANTONIO MANOEL DA CRUZ RODRIGUES3², \\ EDNA REGINA AMANTE ${ }^{3}$, LUIZA HELENA MELLER DA SILVA ${ }^{3}$
}

\begin{abstract}
This study evaluated the chemical composition of peeled and unpeeled green banana Cavendish (AAA) flour obtained by drying in spouted bed, aiming at adding nutritional value to food products. The bananas were sliced and crushed to obtain a paste and fed to the spouted bed dryer $(12 \mathrm{~cm}$ height and $\mathrm{T}=80^{\circ} \mathrm{C}$ ) in order to obtain flour. The flours obtained were subjected to analysis of moisture, protein, ash, carbohydrates, total starch, resistant starch, fiber. The green banana flours, mainly unpeeled, are good sources of fiber and resistant starch with an average of $21.91 \mathrm{~g} / 100 \mathrm{~g}$ and $68.02 \mathrm{~g} / 100 \mathrm{~g}$ respectively. The protein content was found in an average of $4.76 \mathrm{~g} / 100 \mathrm{~g}$, being classified as a low biological value protein with lysine as the first limiting amino acid. The results showed that unpeeled green banana flour obtained by spouted bed drying can be a valuable tool to add nutritional value to products in order to increase their non-digestible fraction.
\end{abstract}

Index terms: green banana, flour, starch, fiber, spouted bed.

\section{POTENCIAL NUTRICIONAL DA FARINHA DE BANANA VERDE OBTIDA POR SECAGEM EM LEITO DE JORRO}

RESUMO-Este estudo avaliou a composição química da farinha de banana verde sem casca e com casca, obtido por secagem em leito de jorro, com o objetivo de agregar valor nutricional a produtos alimentícios. As bananas foram cortados e trituradas para a obteção de uma pasta, sendo esta alimentada no secador leito de jorro $\left(12 \mathrm{~cm}\right.$ de altura e $\mathrm{T}=80^{\circ} \mathrm{C}$ ), a fim de obter uma farinha. As farinhas obtidas foram submetidas a análise da umidade, proteína, cinzas, Carboidratos totais, amido total, amido resistente, e fibras. As farinhas de banana verde, principalmente com casca, são boas fontes de fibras e amido resistente, com uma média de $21,91 \mathrm{~g} / 100 \mathrm{~g}$ e $68,02 \mathrm{~g} / 100 \mathrm{~g}$ respectivamente. O teor médio de proteína encontrado foi para $4,76 \mathrm{~g} / 100 \mathrm{~g}$, sendo classificada como uma proteína de baixo valor biológico, tendo a lisina como o primeiro aminoácido limitante. Os resultados mostraram que a farinha de banana verde com casca obtida por secagem em leito de jorro pode ser uma ferramenta valiosa para agregação de valor nutricional aos produtos, a fim de aumentar a sua fracção não digerível.

Termos para indexação: Banana verde, farinha, amido,fibra,leito de jorro.

\footnotetext{
1'(Trabalho 121-13). Recebido em: 14-03-2013. Aceito para publicação em: 12-11-2013.

${ }^{2}$ Federal University of Para, Faculty of Food Engineering, Laboratory of Physical Measurements, Rua Augusto Corrêa w/n, 66075900 Belém-PA, Brazil; E-mail: cvb@ufpa.br; amcr@ufpa.br; lhmeller@ufpa.br.

${ }^{3}$ Federal University of Santa Catarina, Department of Food Science and Technology, Laboratory of Fruit and Vegetable, Rodovia Admar Gonzaga 1346, 88034-001 Florianópolis-SC, Brazil; E-mail: eamante@cca.ufsc.br
} 


\section{INTRODUCTION}

Banana, the largest herbaceous plant in the world, is among the ten most important crops in Brazil, which is the fourth largest producer in the world at over 7 million tones, produced by conventional cultivation systems (IBGE, 2012, RIBEIRO et al., 2012). One aspect of the Brazilian development, mainly due to the country's agricultural trait, is related to the development of its agro-industrial sectors. Like the sugarcane and citrus production complexes, other sectors of socioeconomic importance have been explored with a comprehensive view in order to bring greater added value to agricultural products, avoid food waste, increase farmers' income, and develop alternative and nutritious food raw material (BORGES et al., 2009).

In the green stage, banana stands out for having a high starch/resistant starch content, deserving industrial interest for developing new products. Moreover, it has a wide range of vitamins and minerals present in both pulps and peels (LIMA et al., 2000). The green banana mass, a material obtained by grinding fresh bananas, dates from the mid-90s and has been studied for food production of green banana pulp mass (GBPM) and green banana peel mass (GPPM). And since it is highstarch-content biomass, it has gained ground in the development of products such as breads, gnocchi, pates, mayonnaise, pasta, and others (BORGES et al., 2009; VERNAZA et al., 2011).

Flour, the main byproduct of green banana, is one of the most common forms of preserving bananas as well as their masses. It has high starch content and is widely used in infant feeding as a source of energy and also has excellent medicinal properties, especially for cases of gastrointestinal infection (MARTINEZ et al., 2009).

Green banana is a food of great value recommended for several pathological conditions, including constipation and diarrhea, due to its ability to normalize colon functions. Since it has the ability to stimulate the proliferation of beneficial acidophilus bacteria in humans, its intake is recommended in cases of colitis, ulcerative colitis, gastric ulcer, uremia, nephritis, gout, cardiovascular disease, and celiac disease. When it is in the green stage, banana is considered to be a functional food of the prebiotic type (MASTRO et al., 2007). The most important factor for considering green bananas as a prebiotic food is its resistant starch content, characterized by the portion of the granule or its degradation products that are not digested or absorbed in the small intestine and are fermented in the large intestine (TEIXEIRA et al., 1998, ACEVEDO et al., 2012).

Another part of the banana that can be mentioned when one aims at increasing nondigestible fraction is the fibers contained in the peel. Just as resistant starches, fibers are not digested by the human organism due to the absence of enzymes capable of digesting this structure. Thus, undigested fiber is fermented by the colonic flora, which generates extremely interesting by products for human health.

\section{METHODS}

Obtaining banana flour

Green (stage 2 of ripening: all green) (AURORE et al., 2009) Cavendish (Musa acuminate) banana was purchased from a local supermarket in Belém, Pará, Brazil. The fruits were washed and separated into two lots: one containing the whole fruit (pulp and peel) and the other only the pulp. To reduce the enzymatic browning, the two lots were dipped in $0.5 \%(\mathrm{w} / \mathrm{v})$ citric acid solution for $10 \mathrm{~min}$ and drained. The lots were crushed in a blender (Poli model LB-15, Brusque, Santa Catarina, Brazil) until a homogeneous paste was obtained, which was subsequently fed into the dryer.

Drying experiments were performed in a conical spouted bed dryer with continuous feeding (Figure 1). The dryer consists of a conical base with an internal angle of $60^{\circ}$ and an inlet orifice diameter of $50 \mathrm{~mm}$. A cylindrical column with diameter of 200 $\mathrm{mm}$ and height of $300 \mathrm{~mm}$ is connected to the conical base of the dryer. The upper part of the equipment is composed of another cone and a cyclone. The operation started with the introduction of $1,036 \mathrm{~g}$ of inert material into the equipment. Spouting occurred when air was injected at the base of the bed. When the spout was established, the inlet air was heated to the desired temperature. The working temperature in the study was $80^{\circ} \mathrm{C}$ and drying air flow rate was fixed at $50 \mathrm{~m}^{3} / \mathrm{h}$. Polyethylene pellets were used as the inert material with a diameter of $3.60 \mathrm{~mm}( \pm 0.02$ $\mathrm{mm})$, a density of $905.23 \mathrm{~kg} / \mathrm{m}^{3}\left( \pm 3.82 \mathrm{~kg} / \mathrm{m}^{3}\right)$, and a sphericity of 0.850 , while the height of particles studied was fixed at $12 \mathrm{~cm}$. The green banana paste to be dried was fed continuously to the drying chamber at a constant rate of $3.91 \mathrm{~mL} / \mathrm{min}( \pm 0.15 \mathrm{~mL} / \mathrm{min})$ into the annular sliding layer from both sides by a peristaltic pump. The fine dried particles were separated from the outlet air in a cyclone and a bag filter. All the drying experiments were carried out in triplicate for each temperature. The flour samples were stored in air-tight plastic packs at ambient temperature $\left(25 \pm 2{ }^{\circ} \mathrm{C}\right)$ for further analysis. 
Chemical composition of flour

The chemical composition of all samples was determined according to the following methods by the AOAC (CUNNIFF, 1997): moisture method 925.10, proteins method 920.152, lipids method 922.06, ash method 923.03, total dietary fiber method 985.29, and carbohydrates from the difference.

\section{Amino acids analysis}

The amino acid profile was determined using total nitrogen content through the AOAC (CUNNIFF, 1997) 920.152 and Kjeldahl methods. Amino acids were obtained by hydrolysis from protein by $6 \mathrm{M}$ hydrogen chloride at $100{ }^{\circ} \mathrm{C}$. After that, the amino acids were reacted with phenylisothiocyanate and the solution was immediately injected into the HPLC system (Waters, USA). Free amino acids were separated using a Waters WAT010950 Pico-Tag free amino acid column (Waters, USA) at $50{ }^{\circ} \mathrm{C}$ and detected with a UV detector at $254 \mathrm{~nm}$.

\section{Total starch and resistant starch}

Starch content was determined through hydrolysis of the samples dried in an acidic medium, using $1.0 \mathrm{~g}$ of sample in $50 \mathrm{~mL}$ of $1 \mathrm{~mol}^{-1} \mathrm{HCl}$ in a microwave oven, in water bath for 10 minutes at full power, as adapted by (CEREDA et al., 2004). The iodine test (I-KI) was used to confirm hydrolysis. After cooling and being added to 1 mol.L $\mathrm{L}^{-1} \mathrm{NaOH}$ $(50 \mathrm{~mL})$, the samples were diluted with distilled water to $250 \mathrm{~mL}$. Sugar was determined by LayneEynon titration.

For the determination of resistant starch, the (AACC, 1999) method no. 76-30A was used (with adaptations). Triplicate samples of $100 \mathrm{mg}$ were analyzed in Falcon tubes of $15 \mathrm{~mL}$. The samples were pre-washed twice with $8 \mathrm{~mL}$ of $80 \%$ ethanol $(\mathrm{v} / \mathrm{v})$, centrifuged (958 RCF) for 10 minutes. Residues were added to $4 \mathrm{~mL}$ of trismaleate/ $0.1 \mathrm{M} \mathrm{NaOH}(\mathrm{pH}$ 6) containing $0.02 \%$ sodium azide, amyloglucosidase (4U/mL, Sigma Aldrich $®$ A 7255), $\alpha$-amylase (300U/mL, Sigma Aldrich $\AA$ A-3176), and pepsin (500U/mL, Sigma Aldrich $\AA$ P-7012). The tubes were shaken, covered, and incubated at $37^{\circ} \mathrm{C}$ for 16 hours under stirring. After incubation, $8 \mathrm{~mL}$ of $99 \%$ ethanol were added and the tubes were shaken and centrifuged (958 RCF) for 10 minutes, uncovered. Rinsing with ethanol was repeated once more.

The tubes containing the waste and magnetic stirring bar magnets were partially submerged in an ice bath and $3 \mathrm{~mL}$ of $2 \mathrm{M} \mathrm{KOH}$ were added under stirring. After 20 minutes, $10 \mathrm{~mL}$ of $\mathrm{NaAc} / \mathrm{HAc}$ - sodium acetate buffer-glacial acetic acid-1.2M (pH $=3.8$ ) were added and the stirring was stopped. Next, $0.1 \mathrm{~mL}$ of amyloglucosidase (NaAc 3200U/ $\mathrm{mL}$ buffer/HAc, $\mathrm{pH}=4.75$ ) was added to the tubes and after the addition they were incubated in a water bath at $50{ }^{\circ} \mathrm{C}$ for 30 minutes under constant agitation. After incubation, the tube content was made up to a volume of $20 \mathrm{~mL}$ with distilled water and then centrifuged (958 RCF) for 10 minutes. The tubes were placed in a spectrophotometer for reading. The resistant starch content was calculated using Equation 1.

Resistant starch $(\%)=\frac{\text { Weight of insoluble residue }(\mathrm{g})}{\text { Sample weight }(\mathrm{g})} 100$

\section{RESULTS}

The chemical composition of banana flour is found in Table 1. Significant differences are seen for the unpeeled sample in lipid fractions, ash, and fiber when compared with the peeled sample, a behavior also found by (GODIM et al., 2005) while working with Pavocan variety in green stage.

The use of banana peel as part of the meal may be a strategy of adding value mainly for the fibers where the differences were more significant (Table 1). The fruit's peel has a high mineral content and its cell walls have high fiber content, especially insoluble such as cellulose and hemicellulose, which are the reasons for its increased contents when compared with the fruit pulp (PEREIRA et al., 2013). The recommended daily fiber intake is between 25 to $30 \mathrm{~g}$ and insoluble fibers should make up the largest part of the intake (70 to $75 \%$ ).Knowing the soluble fiber/insoluble fiber ratio is important for the assessment of functional properties, which is mentioned in the literature at 1:2 and 1:3 (MAHAN; ESCOTT-STUMP, 2003; FIGUEROLA et al., 2005).

In this paper, there was a high carbohydrate content, over $70 \%$ of which corresponding to starch, being more than half of that resistant starch $(36 \%)$. Similar results were found by (MARTINEZ et al., 2009, BEZERRA et al., 2013).

Green banana flour can be regarded as a source of resistant starch and may be used for functional food purposes in the prevention or reduction of cholesterol, constipation, diverticulitis, and colon cancer. Resistant starch intake in Europe and Latin America is low (3 to $6 \mathrm{~g}$ /day) when compared to consumption in other continents like Asia (8-19 g/day). However, there is huge potential to increase this nutrient through food products with high resistant starch content, and green banana flour 
can be one of them (CARDENETTE et al., 2004). Many researchers have prepared products using green banana flour in order to increase the non-digestible fraction, represented by resistant starch and fibers when unpeeled bananas are used (JUAREZ et al., 2006; APARICIO et al., 2007; RODRIGUEZ et al., 2008; MARTINEZ et al., 2009).

Since the resistant starch content may be modified by some types of processing, this study evaluated whether the drying process used had an influence on resistant starch content. The results are shown in Table 2, although the pulps have high moisture content and were subjected to drying temperatures above the gelatinization temperature of starch, beyond favorable conditions for resistant starch formation, no significant differences were found in the values of resistant starch in pulp and flours.

This behavior can be explained by the characteristic of spouted bed drying, being the contact from the feedstock with the drying temperature very fast, which does not allow for starch gelatinization to occur at the contact time. Using spouted bed drying maintained the resistant starch content of banana in natura. Different results were found by (TRIBESS et al., 2009) when assessing the formation of resistant starch in green banana flour subjected to different drying conditions in a fixed bed, showing that the contact time can influence the resistant starch content.

The scientific evidence of non-digestible fraction as functional food is strong. (SHIH et al., 2007) demonstrated the positive effect of resistant starch intake in reducing the levels of glycated hemoglobin, fructosamine, and cholesterol as an improvement in antioxidant status in diabetic rats due to the increase in superoxide dismutase activity and decreased levels of malondialdehyde. Ramakrishna et al. (2000) noted a great reduction in frequency of diarrhea when resistant starch was added to the hydration pretreatment; the study was replicated using green bananas as a source of resistant starch and the authors obtained the same results (SCARMINIO et al., 2012). A reduction effect of resistant starch from banana in intestinal inflammation with fewer macroscopic and microscopic lesions, suggesting that introducing green banana flour into the diet can be a complementary strategy in the treatment of patients with intestinal inflammation (SCARMINIO et al., 2012; RABBANI et al., 2009).

Study concluded in their study that the addition of resistant starch to meals caused a significant increase in lipid oxidation in healthy subjects, noting that the constant consumption of resistant starch may be important for preventing the accumulation of fat in the long term and that the addition of resistant starch in the diet confers important metabolic benefits compared to diets without resistant starch (HIGGINS et al., 2004).

The consumption of resistant starch can interfere in the action of oncogenic diets with high protein content due to the reduction of toxic products in the colon region (LE LEU et al., 2007).

The essential amino acid profile and chemical score value of green banana flour is found in Table 3 . The protein of green banana is considered of low biological value, being lysine the first limiting amino acid. Regarding amino acid profile and analyzing the chemical scores, green banana flour by itself is not a source of protein of high biological value. However, knowing the amino acid profile and limiting amino acids, this can be overcome by combining this flour with other vegetable protein sources (cereal and legume), thus obtaining a final mix with products of better amino acid profile. Rice and beans are a possible combination which ensures improved amino acid profiles (CINTRA et al., 2007). The amino acid profile was determined only for the unpeeled green banana flour since it had the best results for fiber and resistant starch content. 
TABLE 1 - Average composition of the banana flours.

\begin{tabular}{lcc}
\hline \multicolumn{1}{c}{ Components $(\mathbf{g} / \mathbf{1 0 0 g})$} & Unpeeled & Peeled \\
\hline & $4.33 \pm 0.08^{\mathrm{a}}$ & $4.14 \pm 0.07^{\mathrm{a}}$ \\
Protein & $0.701 \pm 0.001^{\mathrm{a}}$ & $0.453 \pm 0.009^{\mathrm{b}}$ \\
Ashids & $2.72 \pm 0.08^{\mathrm{a}}$ & $1.084 \pm 0.06^{\mathrm{b}}$ \\
Carbohydrates & $83.94 \pm 0.09^{\mathrm{a}}$ & $86.92 \pm 0.08^{\mathrm{b}}$ \\
Total starch & $68.42 \pm 0.51^{\mathrm{a}}$ & $78.43 \pm 1.83^{\mathrm{b}}$ \\
Resistant starch & $33.86 \pm 0.56^{\mathrm{a}}$ & $40.14 \pm 0.34^{\mathrm{b}}$ \\
Total fiber & $15.52 \pm 0.23^{\mathrm{a}}$ & $8.49 \pm 0.67^{\mathrm{b}}$ \\
Soluble fiber & $2.07 \pm 0.26^{\mathrm{a}}$ & $1.34 \pm 0.32^{\mathrm{a}}$ \\
Insoluble fiber & $13.45 \pm 0.34^{\mathrm{a}}$ & $7.15 \pm 0.48^{\mathrm{b}}$ \\
Soluble fiber/insoluble fiber ratio & $1: 6$ & $1: 5$ \\
\hline
\end{tabular}

Mean values of three replicates \pm standard deviation.

Different letters between columns represent significant differences at $95 \%$.

TABLE 2 - Resistant strach content (\%) in pulp and green banana flour.

\begin{tabular}{cclcc}
\hline Assay & \multicolumn{2}{c}{ Unpeeled } & \multicolumn{2}{c}{ Peeled } \\
\hline $\mathrm{T}\left({ }^{\circ} \mathrm{C}\right)$ & Pulp & Flour & Pulp & Flour \\
& & & & \\
\hline 80 & $35.625 \pm 0.17^{\mathrm{a}}$ & $35.065 \pm 0.15^{\mathrm{a}}$ & $42.38 \pm 0.51^{\mathrm{a}}$ & $42.04 \pm 0.17^{\mathrm{a}}$
\end{tabular}

TABLE 3 - Essential amino acid profile of green banana flour.

\begin{tabular}{lccc}
\hline \multicolumn{1}{c}{ Amino Acid (AA) } & \multicolumn{3}{c}{ Amino acid content (mg/g) } \\
\hline Essential Amino Acid & Green Banana Flour & FAO/WHOA Standards & Chemical Score \\
Histidine & 0.41 & 23 & 0.01782 \\
Threonine & 0.32 & 33 & 0.00969 \\
Lysine & 0.07 & 36 & 0.00194 \\
Methionine + Cysteine & 0.11 & 37 & 0.00297 \\
Isoleucine & 0.19 & 42 & 0.00452 \\
Leucine & 0.23 & 82 & 0.00280 \\
Valine & 0.20 & 58 & 0.00344 \\
Phenylalanine + Tyrosine & 0.58 & 80 & 0.00725 \\
\hline
\end{tabular}




\section{CONCLUSIONS}

Green banana flour, especially unpeeled, can be an important ingredient when the aim is to increase the non-digestible fraction in food and may have positive effects on health, which have already been demonstrated in the literature. The drying process used in this study did not alter the values of resistant starch, guaranteeing the same content as compared to raw material in natura. The characteristics found indicate a promising use of green banana flour in the preparation of food products for intestinal inflammation and celiac disease patients. Besides adding nutritional value to food products, unpeeled green banana flour also stands out for not creating production waste, thus representing the complete use of the fruit, increasing the yield and reducing manpower cost due to peeling was not required.

\section{ACKNOWLEDGMENTS}

The authors are thankful to FAPESPA (Process 058/2008), CNPq (Process 620209/20089), CAPES (PROCAD- NF process 2256/2008) and PROPESP/UFPa.

\section{CONFLICT OF INTEREST}

The authors declare no conflict of interest.

\section{REFERENCES}

AURORE, G.; PARFAIT, B.; HRASMANE, L. Bananas raw materials for making processed food products. Trends in Food Science Technology, Cambridge, v.20, n.2, p. 78-91, 2009.

AACC - American Association of Cereal Chemists. Approved methods. $15^{\text {th }}$ ed. St Paul, 1999.

ACEVEDO, E.A.; HERNANDEZ, J.J.I.; VARGAS, G.P.; DIAZ, P.O.; PEREZ, L.A.B. Starch digestibility and glycemic index of cookies partially substituted with unripe banana flour. Food Science and Technology, Cambridge, v.46, n.1, p.177-182, 2012.

APARICIO, A.S.; SAYAGO, A.S.G.; VARGAS, T.A.; JUSCELINO, T.; ASCENCIO, O.T.E.; BELLO, P.L.A. Slowly digestible cookies prepared from resistant starch-rich lintnerized banana starch. Journal of Food Composition and Analysis, Paris, v.20, n.3-4 p.175-181, 2007.
BEZERRA, C.V.; AMANTE, E.R.; OLIVEIRA, D.C.; RODRIGUES, A.M.C.; SILVA, L.H.M. Green banana (Musa cavendishii) flour obtained in spouted bed - effect drying on physic - chemical, functional and morphological characteristics of the starch, Industrial Crops Products, Netherlands, v.41, p.241-249, 2013.

BORGES, A.M.; PEREIRA, J.; LUCENA, E.M.P. Green banana flour characterization, Food Science Technology, Cambridge, v.2, p.333-339, 2009.

CARDENETTE, G.H.L.; MENEZES, E.W.; LAJOLO, F.M.; MELO, A.T., Measurement of carbohydrate components and their impact on energy value of foods. Journal of Food Composition and Analysis, Paris, v.17, n.3-4 p.331-338, 2004.

CEREDA, P.M.; DAIUTO, R.E.; VILPOUX O. Methodology for determining starch in microwave acid digestion. Revista ABAM, Curitiba, v.2, n. 8, p.1-29, 2004.

CINTRA, R.M.C.G.; MAGALHÃES, C.O.; GARCIA, R.R.; MELLO, R.S.; PADILHA, A.; KUSAI, C.; CAETANO, L. Avaliação da qualidade da proteína de arroz e feijão e de dieta da região sudeste do Brasil. Alimentos e Nutrição, Araraquara, v.18, n.3, p. 283-289, 2007.

CUNNIFF, P. (Ed.). Official methods of analysis. $16^{\text {th }}$ ed. Gaithersbug: AOAC, 1997. v.1, $1141 \mathrm{p}$.

FIGUEROLA, F.; HURTADO, M.L.; ESTÉVEZ, A.M.; CHIFFELLE, I.; ASENJO, F. Fibre concentrates from apple pomace and citrus peel as potential fibre sources for food enrichment. Food Chemistry, London, v.91, n.3, p.395-401, 2005.

GODIM, J.A.M.; MOURA, M.F.; DANTAS, A.S.; MEDEIROS, R.L.; SANTOS K.M. Composição centesimal e de minerais em cascas de frutas. Ciência e Tecnologia de Alimentos, Campinas, v.25,n.4, p.825-827, 2005.

HIGGINS, J.A.; HIGBEE, D.R.; DONAHOO, W.T.; BROWN, I.L.; BELL, M.L.; BESSESEN, D.H. Resistant starch consumption promotes lipid oxidation. Nutrition and Metabolism, Basel, v. 1, p. 1-11, 2004. 
IGBE - Instituto Brasileiro de Geografia e Estatística. Dados de previsão de safra. Disponível em: $<$ http://www.sidra.ibge.gov.br/bda/prevsaf/default. asp? $\mathrm{z}=\mathrm{t} \& \mathrm{o}=26 \& \mathrm{i}=\mathrm{P}>$. Acesso em: 27 nov. 2012

JUAREZ, G.A.; AGAMA, A.E.; SAYA, A.S.L.; RODRIGUEZ, A.S.L.; BELLO-PEREZ LA. Composition digestibility and application in breadmaking banana flour. Plant Foods for Human Nutrition, Netherlands, v.61, n.3, p.131-137, 2006.

LELEU, R.K.; BROWN, I.L.; HU, Y.; MORITA, T.; ESTERMAN, A.; YUNG, GP. Effect of dietary resistant starch and protein on colonic fermentation and intestinal tumourigenesis in rat. Carcinogenesis, Oxford, v. 28, n.2, p.245-250, 2007.

LIMA, B.G.A.; NEBRA, A.S.; QUEIROZ, R.M. Scientific and technological aspects of banana. Revista Brasileira de Produtos Agroindustriais, Campina Grande, v.2, n.1 p.87-101, 2000.

MAHAN, L.K.; ESCOTT-STUMP, S. Krause: alimentos, nutrição e dietoterapia. 10. ed. São Paulo: Roca, 2003.

MARTINEZ, M.O.; AYERDI, S.S.; AGAMA, E.C.; GONI, I.; BELLO, P.L.A. Unripe banana flour in the ingredient to the increase of carbohydrate indigestible paste. Food Chemistry, London, v.113, p.121-126, 2009.

MASTRO, N.L.; TAIPINA, M.S.; COHEN, V.H.; RODAS, M.A.B.;GARBELOTTI, M.L. Avaliação critica da polpa de banana (Musa spp) verde. Revista Higiene Alimentar, São Paulo, v. 21, p. 39-45, 2007.

PEREIRA, M.C.A.; BARCELOS, M.F.P.; SOUSA, M.S.B.; PEREIRA, J.A.R. Effects of the kefir and banana pulp and skin flours on hypercholesterolemic rats. Acta Cirúrgica Brasileira, São Paulo, v.28, p.481-486, 2013.

RABBANI, G.H.; SHAMSIR, A.; HOSSAIN, I.; ISLAM, R.; MARNI, F.; AKHTAR, M. Green banana reduces clinical severity of childhood shigellosis: a double-blind, randomized control clinical trial. The Pediatric Infectious Disease Journal, Baltimore, v.5, p. 420-425, 2009.
RAMAKRISHNA, B.S.; VENKATARAMAN, S.; SRINIVASAN, P.; DASH, P.; YOUNG, G.P.; BINDER, H.J. Amilase-resistant starch plus oral rehydration solution for cholera. New England Journal of Medicine, Waltham, v.342, p.308-313, 2000 .

RIBEIRO, L.R.; OLIVEIRA, L.M.; SILVA, S.O.; BORGES, A.L. Physical and chemical characterization of bananas produced in conventional and organic cultivation systems. Revista Brasileira de Fruticultura, Jaboticabal, v.34, n.3, p.774-782, 2012.

RODRIGUEZ, A.S.L.; ISLA, H.J.J.; AGAM, A.E.; TOVAR, J.; BELLO-PEREZ, L.A. Characterization of a fiber-rich powder prepared by liquefaction of unripe banana flour. Food Chemistry, London, v.107, n.4, p.1515-1521, 2008.

SCARMINIO, V.; FRUET, A.C.; WITAICENIS, A.; RALL, V.L.; DI STASI, L.C. Dietary intervention with green dwarf banana flour (Musa sp AAA) prevents intestinal inflammation in a trinitrobenzesulfonic Acid Model of Rat Colitis. Nutrition Research, Tarrytown, v.3, p.202-209, 2012.

SHIH, C.K.; CHEN, S.H.; HOU, W.C.; CHENG, H.H.A. High-resistance - starch rice diet reduces glycosylated hemoglobin levels and improves the antioxidant status in diabetic rats. Food Research International, Barking, v.40, n.7, p. 842-847, 2007.

TEIXEIRA, M.A.V.; CIACCO, C.F.; TAVARES, D.Q.; BONEZZI, A.N. Occurrence and characterization of resistant starch in corn starch and banana. Food Science and Technology, London, v.2, p.243-253, 1998.

TRIBESS, T.B.; HERNANDEZ, J.P.; MONTEALVO, M.G.C.; MENEZES, E.W.; BELLO-PEREZ, L.A.; TADINI, C.C. Thermal properties and resistance starch content of green banana flour (Musa cavendishii) produced at different drying conditions. Food Science and Technology, London, v.42, p.1022-1025, 2009.

VERNAZA, M.G; GULARTE, M.A; CHANG, Y.K. Addition of green banana flour to instant noodles: rheological and technological properties. Ciência Agrotecnologia, Lavras, v.35, n.6, p.1157-1165, 2011. 